$\mid \begin{array}{cc}\mathbf{C}|\mathbf{O}| \mathbf{P}|\mathbf{E}| & \text { Turyzm/Tourism } \\ \substack{\text { Member since } 2019 \\ \text { JMM 14487 }} & 2021,31 / 2\end{array}$

\title{
ENTREPRENEURSHIP IN COMMUNITY-BASED TOURISM IN SRI LANKA
}

\author{
Indika Priyantha Kaluarachchige ${ }^{\text {iD }}$, Mohd Shukri Ab Yajid ${ }^{\text {(ID), }}$ \\ Ali Khatibic iD, S.M. Ferdous Azam ${ }^{\mathrm{d}}$
}

\footnotetext{
${ }^{a}$ Management and Science University (MSU) Malaysia; University College of Matara (UCM) Sri Lanka, Division of Management Studies; http://orcid.org/0000-0002-7489-5279; e-mail: indikapri@gmail.com

${ }^{\mathrm{b}}$ Management and Science University (MSU) Malaysia; https://orcid.org/0000-0001-5688-4392; e-mail: shukri@msu.edu.my

${ }^{c}$ Management and Science University (MSU) Malaysia, Post Graduate Centre; https://orcid.org/0000-0002-2531-7720; e-mail: alik@msu.edu.my

d Management and Science University (MSU) Malaysia, Post Graduate Centre; https://orcid.org/0000-0002-0001-3595; e-mail: drferdous@msu.edu.my
}

How to cite (APA style): Kaluarachchige, I.P., Yajid, M.S.A., Khatibi, A., Azam, S.M.F. (2021). Entrepreneurship in community-based tourism in Sri Lanka. Turyzm/Tourism, 31 (2), 87-101. https://doi.org/10.18778/0867-5856.31.2.05

\begin{abstract}
This study is focused on entrepreneurship in community-based tourism (CBT) in Sri Lanka. It examines the effect of entrepreneurial competences and orientation towards the performance of homestays although the majority are not successful. Recent research has revealed that homestay tourism is not effective, nonetheless it has been identified as the sector for the development for entrepreneurs and can make a considerable contribution to the Sri Lankan economy. The purpose of this study is to enhance CBT by showing how to develop productive entrepreneurs in this sector. Resource based view (RBV) theory is the basis - 645 registered homestay units operate as a CBT practice and the study sample was 252 entrepreneurs. Structural equation modelling (SEM) was used to analyze the data. From the findings of the study, both entrepreneurial competences and orientation significantly affect entrepreneur performance in CBT. This study will help expand CBT for successful entrepreneurs emerging from the tourism sector.
\end{abstract}

\section{KEYWORDS}

entrepreneurial competences, entrepreneurial orientation, community-based tourism

\section{ARTICLE INFORMATION DETAILS}

Received:

8 September 2021

Accepted:

21 October 2021

Published:

21 December 2021

\section{INTRODUCTION}

Recently, entrepreneurs and entrepreneurship have become widespread around the world and are the driving force of economic activity in every country (Vashishtha, 2021). Entrepreneurship is the practice of introducing innovative products or services through the formation of new businesses or continuing an existing one (Sajeena, 2020). Recent decades have witnessed the rapid spread of entrepreneurship all over the world (Catalin, George, Razvan, 2017). Most countries heavi- ly depend on these firms' performances to stimulate and grow their economies (Hallam, Dosamantes, Zanella, 2017), entrepreneurship is subsequently significant in that it is able to drive and grow the productivity of business ventures (Sok, Snell, Lee, Sok, 2017).

Entrepreneurship is the ability and readiness to organize, advance and accomplish a business enterprise together with its risks in order to gain a profit (Business Dictionary, 2020). The competences of an entrepreneur are distinguished as a cluster connected to productive 
entrepreneurship and is normally associated with the innovation, survival and growth of a firm (Carayannopoulos, 2017). Moreover, the orientation of entrepreneurs is considered as the ability to track the behaviour of the firm via risk taking, innovation and proactiveness (Dada, Fogg, 2016; De Clercq, Dimov, Thongpapanl, 2015; Reijonen, Tammi, Saastamoinen, 2015) and this relates to a firm's performance (Gupta, Batra, 2015).

Entrepreneurship has always been a recognized practice in the tourism industry and its development in any country encourages entrepreneurial practice. Considering the entrepreneurship opportunities it is one of the major areas where they are unlimited and tourism has immense potentiality (Sikari, 2018). Community participation positively relates to success among homestay entrepreneurs (Yong, Hassan, 2017) and in order to be carried out successfully in the future, entrepreneurs who belong to the community and involved as homestay operators, will have to make a considerable contribution. They must have entrepreneurships skills (Kayat, Zainuddin, Ramli, Kasim, 2016) which are very important (Witchayakawin, Aziz, Mahomed, Abdullah, 2020).

CBT enables communities to participate in tourism related activities by operating as a substitute accommodation business for community groups that want to engage in tourism activities (Junaid, Salam, Salim, 2019). Homestay is a CBT programme that gives exciting experience around a local culture to visitors as an alternative tourism product. They have become popular in many countries due to the experience of tourists who want to interact with local culture, its social system, lifestyle, language, people and helping develop its socioeconomic status via the tourism industry (Wijesundara, Gnanapala, 2015).

Sri Lanka as a country, should strive to encourage entrepreneurship via the expansion of an entrepreneurial culture. In this attempt, innovation and creativity will certainly play important roles to accomplish growthoriented objectives with a competitive advantage over other countries. When an entrepreneurial culture is established, it is important for potential investors and capitalists to initiate and continue business there since it may be a real inducement for them. Therefore, Sri Lanka is to make an entrepreneurial culture that is a part of the life of people within this country (Perera, 2018). Homestay has great potential for local firms as a business operation (Ranasinghe, 2015). The Sri Lanka Tourism Development Authority (SLTDA) took the initiative by empowering the local community to utilize their expertise and ability to become entrepreneurs (Sriyani, 2018). This study hopes to enhance entrepreneurship in CBT in Sri Lanka.

\section{RESEARCH ISSUE}

The majority of homestay units are not successful as recent research has shown in the Sri Lankan context (Ranasinghe, 2015; Sriyani, 2018; Wijesundara, Gnanapala, 2015). Sriyani (2018) highlighted that despite the popularity of homestays, severe problems may hinder their success and survival. Wijesundara and Gnapala (2015) revealed that homestay tourism does not work well as an alternative tourism product.

Considering the recent research conducted by Croos, Kumara, Nawarathne and Idroos (2020) in the Sri Lankan context, there is great potential to develop CBT by overcoming barriers. There are more opportunities (Madushi, Ranasinghe, Sammani, 2020; Ranasinghe, Damunupola, Kumara, Sammani, 2020; Sumithra, 2020) but there are some challenges and issues (Jayasundara, Tennakoon, Wijesundara, 2020).

Developing entrepreneurial competences is essential to be a successful entrepreneur since they are fundamental to the accomplishment of small business organizations (Sajeena, 2020). In addition, the orientation of entrepreneurs certainly adds to their performance (Alalawi, 2020).

Entrepreneurial competence and orientation have been focused independently on small business performance, but there are few academic works which focus on the theoretical fusion of entrepreneurial orientation and competences (Kaluarachchige, Yajid, Khatibi, Azam, 2021a). Hashim, Raza and Minai (2018) discovered that the association between the competences of entrepreneurs and small business success is doubtful because the outcome of studies related to this association are incompatible. Mitchelmore and Rowley (2013) specified that these would be a base for advance exploration for the competences of entrepreneurs which influence small business achievements. Empirical studies have barely focused the role of entrepreneurial orientation within service organizations and empirical findings are still lacking in linking the variables of entrepreneurial orientation and performance especially in homestay studies (Ahmad, Supian, Muhammad Yunus, Tanius, Ishak, 2019).

Moreover, there may be a research gap in knowledge linked to the competences of entrepreneurs (Yusuff, Bakar, Ahmad, 2016). Thus research is required to further investigate the association between entrepreneurial competence and success (Hashim, Raza, Minai, 2018). Small firm performance is very important for economic achievements, chiefly in developing countries, but research into entrepreneurship is limited (Coder, Peake, Spiller, 2017; Hyder, Lussier, 2016) so, there would be a crucial necessity to conduct research into small size organizations (Hashim, Raza, Minai, 2018). Related 
research ought to be done in developing countries and similar studies would be repeated to confirm these results (Ibrahim, Abu, 2020).

\section{LITERATURE REVIEW}

Entrepreneurship is the practice of setting up a novel business to manufacture and sell innovative, original or prevailing goods or service and small and medium sized enterprises (SME) are a chance for new entrepreneurs (Kaluarachchige, Yajid, Khatibi, Azam, 2021a). Entrepreneurship is viewed as the main growth initiative that leads to job creation, economic development, novelty and competitiveness (Sajeena, 2020). Entrepreneurship is becoming a key concept for economic sustainable development in today's complex and dynamic business world (Akbar, Bon, Wadood, 2020). The entrepreneurial literature emphasizes the role of entrepreneurs in the success of businesses, especially in small business (Tehseen, Ramayah, 2015). The effect of entrepreneurship towards business success has been highlighted in the literature (Monteiro, Rua, Soares, 2019) and much empirical evidence is still required to realize the concept of entrepreneurship (Rauch, 2015). Due to Hyder and Lussier, (2016) small business productivity and challenges should essentially be addressed in developing countries.

Resource-based view (RBV) theory is the basis for this study. It underlines organizations' assets or resources as the key determinants of competitive advantage and performance. In the RBV approach, it is assumed that company resources have four principal dimensions, both tangible and intangible by nature (Wernerfeit, 1984). They determine the sustainable advantage of the firm and should be valuable, rare unique and irreplacable (Barney, 1991). RBV treats human capital characteristics such as competences as intangible resources (Barney, 1991). Traits, capabilities and skills can be transformed into a set of internal unique resources which small businesses need to trust (Lerner, Almor, 2002). RBV applications in the context of small businesses, entrepreneurial orientation and competence are unique management skills which are considered a resource for achieving exceptional enterprise performance.

The construct of entrepreneurial competences is characterized by opportunity, strategic, technical, relationship as well as conceptual (Man, Thomas, Lau, Chan, 2002). Beyond these, Ahmad (2007) recognized twelve competences: risk taking, strategy, technical, commitment, personal, opportunities, learning, knowledge, relationships, decision making, organizing and social responsibility. Man (2001) also discovered clus- ters of competences such as opportunity, learning, relationship, commitment, analytical, strategic, conceptual, innovative, human, organizing, operational and personal strength. Later, Ahmad (2007) added four areas, ethical, technical, familism and social responsibility, to the competence clusters introduced by Man (2001) while he divided conceptual competence into innovative and analytical.

Entrepreneurial orientation can be defined as the strategic position of an organization which shows proactive, innovative and risk-taking attitudes as a whole or in a single dimension (Wales, 2015). Entrepreneurial orientation is said to be a trigger for business model innovation in relation to those aspects that support changes (innovative and proactive) and decision-making trends with a measurable risk (Bouncken, Lehman, Fellnhofer, 2016). It symbolizes the behavior of opportunity seeking in a business renowned for proactiveness, innovativeness and risk taking (Dada, Fogg, 2016; De Clercq, Dimov, Thongpapanl, 2015; Reijonen, Tammi, Saastamoinen, 2015). Due to Gautam (2016), the orientation of entrepreneurs is characterized by five dimensions: innovativeness, pro-activeness, autonomy, competitive aggressiveness and risk taking. Moreover, Haider, Asad and Fatima (2017) emphasized that the orientation of entrepreneurs is characterized by three dimensions: proactiveness, risk taking and innovativeness. Fatoki and Oni (2014) also measured entrepreneurial orientation by using three elements namely innovativeness, risk taking and proactiveness.

Each person has his or her exceptional entrepreneurial orientation and competences which are not easy for competitors to follow (Tehseen, Ramayah, 2015). There is an association between them and business performance (Bahari, Yunus, Jabar, 2017).

Entrepreneurial competences are known to be an assorted assembly of competences which are linked to successful entrepreneurship (Kaluarachchige, Yajid, Khatibi, Azam, 2021b). This entrepreneurship is usually associated with small business enterprises for their development and growth (Carayannopoulos, 2017). Grimmer, Miles, Byrom and Grimmer (2017) examined small business performance depending on strategic factors, but the most significant is the competence of entrepreneurs. According to Peric, Grladinovic, Kropivsek and Greger (2017), business success can be enhanced by entrepreneurial competence.

Entrepreneurship competences play a major part in the expansion and survival of a business organization (Khan, Ali, Jantan, Latiff, 2018). On the other hand, insufficient competences in a small business could create key issues and difficulties in achieving a high business performance (Pulka, Ramli, Mohamad, 2018). The competences of entrepreneurs have been regarded as crucial factors for success and are 
necessary for an organizational transformation for entrepreneurs (Mohsin, Halim, Ahmad, Farhana, 2017). Among the capital most important for an enterprise, entrepreneurial competence is the most valued resource (Sozuer, Altuntas, Semercioz, 2017; Tehseen, Ramayah, 2015).

The positive effect of entrepreneurial competences on organizational performance has been broadly discussed in the literature (Farooq, Abideen, 2015; Tehseen, 2017). Generally, the outcomes of empirical research show their effect on SME achievements (Tehseen, Ramayah, 2015; Yusuff, Bakar, Ahmad, 2016). Many studies argue that a lack of entrepreneurial competence hinders business performance (Tehseen, Ramayah, 2015). Previous research on the link between competences and business success suggests a significant relationship (Nwachukwu, Chladkova, Zufan, 2017) and verifies their positive influence on organizational success (Kabir, Ibrahim, Shah, 2017). There are numerous studies that link competences to small business accomplishments. Similarly, many show that there would be a significant positive effect on the performance of business (Barazandeh, Parvizian, Alizadeh, Khosravi, 2015; Mitchelmore, Rowley, Shiu, 2014; Sarwoko, Surachman, Hadiwidjojo, 2013; Tehseen, Ramayah, 2015). Developing competences in entrepreneurs is essential to success as an entrepreneur and to enhance the performance of a small business as well (Sajeena, 2020).

There is a need for advanced studies on the entrepreneurial competences that influence the success of SMEs (Mitchelmore, Rowley, 2013). Moreover, a knowledge gap in relation to competences still exists (Yusuff, Bakar, Ahmad, 2016), thus additional studies are required on the association between entrepreneurs' competences and small business success (Hashim, Raza, Minai, 2018).

The influence of the orientation of entrepreneurs on small business performance has been investigated in numerous studies (Monteiro, Soares, Rua, 2019). Entrepreneurial orientation is an organizational concept which has frequently been used in entrepreneurial studies (Kaluarachchige et al., 2021b). Many researchers have found a positive influence of entrepreneurial orientation on the performance of small businesses (Lomberg, Urbig, Stockmann, Marino, Dickson, 2016). Likewise, Lisboa, Skarmeas and Saridakis, (2016) investigated many previous studies on the orientation of entrepreneurs and found that a combination of characteristics can be used to explore its impact on business performance. Similarly, Ahmad, Supian, Muhammad Yunus, Tanius and Ishak (2019) concluded that prior academic research relates entrepreneur orientation directly to business performance.

Entrepreneurial orientation usually has a significant influence on business performance (Caseiro, Coelho, 2018). Radulovich, Javalgi and Scherer (2018) discovered that it directly impacts on small business success (Musthofa, Wahyudi, Farida, Ngatno, 2017). In the same way, Tingko and Wenyi (2017) examined how it positively influences business performance while Matchaba-Hove, Farrington and Sharp (2015) stated that there is a direct link between entrepreneurial orientation and business success. The importance of the orientation of entrepreneurs in SME accomplishments has broadly been admitted in the literature (Brouthers, Nakos, Dimitratos, 2015; Gupta, Batra, 2015).

That entrepreneurial orientation positively affects small business performance has been shown by recent research as well (Alalawi, 2020), likewise it influences the performance of SMEs (Igweh, Stephen, 2019; Oni, Agbobli, Iwu, 2019). It can be a predictor of business performance in small firms (Fitriati, Purwana, Buchdadi, Subagja, 2020; Khan, Xuele, Atlas, Khan, 2019; Oni, Agbobli, Iwu, 2019; Sulistyo, Ayuni, 2020).

A deeper analysis of the entrepreneurial orientation dimension in business performance is required (Putnins, Sauka, 2019) and further research is needed (Solikahan, Mohammad, 2019). Ibrahim and Abu (2020) mentioned that parallel research should be undertaken to confirm the results. Further studies are required to establish the nature of the relationship between entrepreneurial orientation and business performance and the aspects that can influence this relationship (Akbar, Bon, Wadood, 2020).

\section{RESEARCH METHOdOLOGY}

The conceptual model for this study was constructed based on the fundamental principles of RBV theory. This enables a reliable framework for the research domain and the results have been verified significantly (Hashim, Raza, Minai, 2018). From the literature, entrepreneurial competences and orientation are known to be predictors of entrepreneur performance. Strategic, commitment, organizing, opportunity, relationship and conceptual competences are the main dimensions of entrepreneurial competence. The main dimensions of entrepreneurial orientation however are proactiveness, risk-taking and innovativeness. Financial and strategic factors are dimensions of entrepreneur performance.

Improvement in entrepreneurial competence will have a direct impact on the improvement of a firm's performance (Sarwoko, Nurfarida, 2018). Nwachukwu, Chladkova and Zufan (2017) indicated that they are paramount to the success of organizations, and previous studies suggest a positive relationship. Thus the first hypothesis was proposed: H1: Entrepreneurial competences significantly impact on performance. Improvement in entrepreneurial orientation will determine the performance 
of a business (Sarwoko, Nurfarida, 2018). It is generally found that entrepreneurial orientation has a positive impact on organizational performance (Caseiro, Coelho, 2018). Similarly, Radulovich, Javalgi and Scherer (2018) demonstrated that entrepreneurial orientation directly affects SME performance. Thus, a second hypothesis was proposed: H2: Entrepreneurial orientation significantly impacts on performance. The present study follows a deductive approach mostly using a positivist research paradigm. In the present study, surveys are used as the main research method and data was collected through primary sources. A structured questionnaire was used as the main research instrument to gather quantitative data. Validity and reliability were properly established and individual entrepreneurs were considered as the unit for analysis.

252 registered homestay entrepreneurs in CBT were considered out of the 645 homestay units registered by the Sri Lankan Tourism Development Authority (SLTDA). Data was collected covering all districts by the disproportionate stratified random sampling method. The questionnaire was sent to 302 subjects, 261 were completed and returned, 9 of which were ignored. The response rate of the present study is $83 \%$. Most respondents are between $35-45$ years old with GCE A level and $O$ level qualifications.

\section{DATA ANALYSIS}

The research uses structural equation modelling (SEM) with a two-stage approach: a measurement model and structural model. The measurement model (see Figure 1) was developed with a combination of 24 items related to the final CFA (Confirmatory Factor Analysis) results [Entrepreneurial Competences (EC) - 9 items, Entrepreneurial Orientation (EO) -9items, Entrepreneur Performance (EP) - 6 items]. Recommended values of indices and model statistics are presented in the Table 1.

Table 1. Results of the measurement model

\begin{tabular}{|l|c|c|c|}
\hline $\begin{array}{c}\text { Fit indices } \\
\text { (goodness of fit) }\end{array}$ & $\begin{array}{c}\text { Accepted values } \\
\text { (cut off value) }\end{array}$ & Result & $\begin{array}{c}\text { Model } \\
\text { evaluation }\end{array}$ \\
\hline Chi square/df & $<3$ & 1.720 & Good fit \\
\hline CFI & $>0.9$ & 0.934 & Good fit \\
\hline RMSEA & $<0.08$ & 0.054 & Good fit \\
\hline
\end{tabular}

Source: authors.

Chi square, CFI (Comparative Fit Index), RMSEA (Root Mean Square Error Of Approximation) indices are close to recommended values and evaluated as a good fit. Therefore 24 items in the final measurement model sufficiently fit the data (Figure 1). This emphasizes that all items make a comparable influence on each construct.

Co-variances in the measurement model are presented in the Table 2.

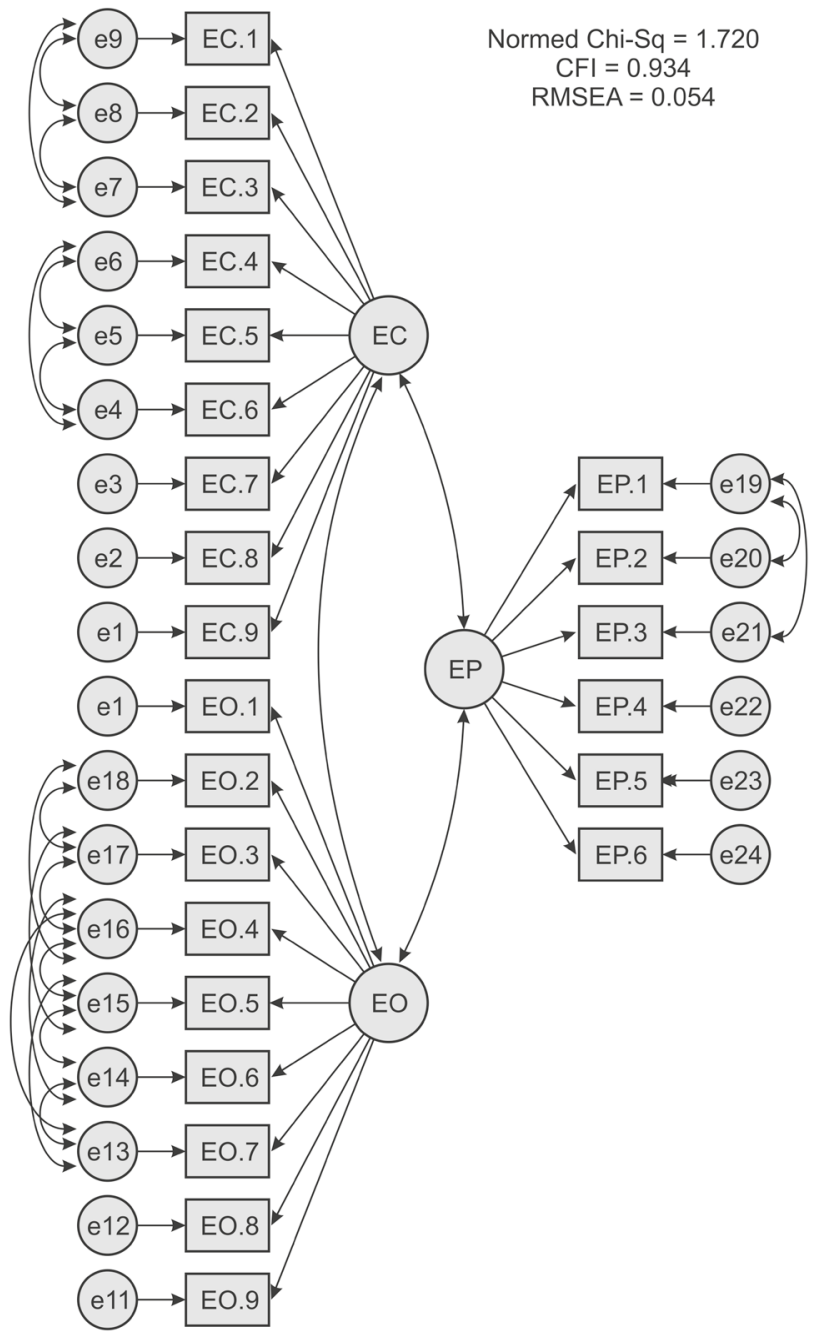

Figure 1. Measurement model Source: authors

Table 2. Co-variances in the measurement model

\begin{tabular}{|l|c|c|c|c|c|}
\cline { 2 - 6 } \multicolumn{1}{c|}{} & Estimate & S.E. & C.R. & P & Correlation \\
\hline E.C. $\leftrightarrow$ E.P. & 0.308 & 0.061 & 5.064 & $* * *$ & 0.411 \\
\hline E.O. $\leftrightarrow$ E.P. & 0.223 & 0.054 & 4.150 & $* * *$ & 0.303 \\
\hline
\end{tabular}

Source: authors.

This section explains the validation of the measurement model (first stage). The structural model can then be assessed and presented as a second stage of structural equation modelling (Hair, Black, Babin, Anderson, Tatham, 2006; Kline, 2005). Byrne (1989) states that the purpose of creating the structural model is to elucidate the relationships (direct or indirect) with other constructs. Figure 2 (see p. 92) shows the final structural model. 


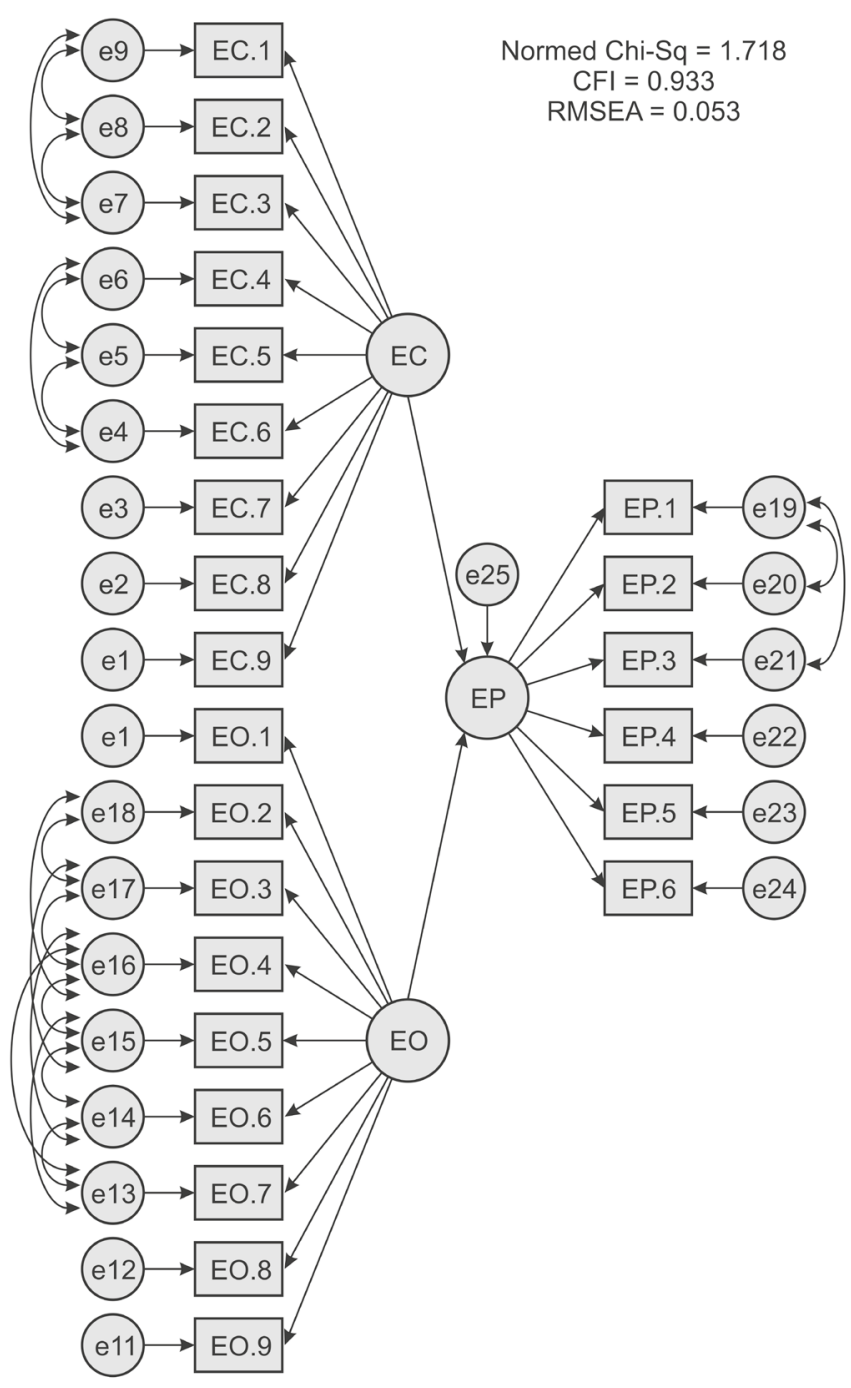

Figure 2. Structural model Source: authors

The outcome of the association between variables (regression weightings) in the final structural model is shown in the Table 3.

Table 3. Regression weightings in the structural model

\begin{tabular}{|c|c|c|c|c|c|}
\cline { 2 - 6 } \multicolumn{1}{c|}{} & $\begin{array}{c}\text { Non-standard } \\
\text { estimate }\end{array}$ & S.E. & C.R. & P & $\begin{array}{c}\text { Standard } \\
\text { estimate }\end{array}$ \\
\hline E.P. $\leftarrow$ E.C. & 0.236 & 0.045 & 5.293 & $* * *$ & 0.357 \\
\hline E.P. $\leftarrow$ E.O. & 0.175 & 0.041 & 4.247 & $* * *$ & 0.258 \\
\hline
\end{tabular}

Source: authors.

The outcomes of the connections between the variables in the final structural model are shown in the table which indicates that there was a significant $(\mathrm{P}<0.01)$ positive effect between entrepreneurial competences and orientation to entrepreneur performance. The most important influences for entrepreneur performance are CBT entrepreneurial competences. The enhancement of competences such as strategic, commitment, organizing, opportunity, relationship and conceptual etc. is important for its development. On the other hand proactiveness, risk-taking and innovativeness are important orientation factors.

\section{CONCLUSION}

This study was based on entrepreneurship in CBT in Sri Lanka. It examines the influence of entrepreneurial competences and orientation towards the performance of entrepreneurs, elucidates the current situation and provides suggestions for entrepreneurship development. From recent research conducted in the Sri Lankan context, most homestay units are not successful as CBT practice and homestay tourism as a substitute tourism creation is not successfully functioning.

From the findings of the study, both entrepreneurial competences and orientation significantly influence entrepreneur performance in CBT. But entrepreneurial competences are more important than orientation. In terms of the research context, this is the first empirical study to consider both the competences and orientation of entrepreneurs in a single investigation to judge an entrepreneurs' performance. Homestay tourism can be used to develop entrepreneurs through CBT by utilizing their orientation and competences in their local communities to make a considerable contribution to the Sri Lankan economy.

Developing competences is very important to become a successful entrepreneur since they affect the success of the homestay business. Competences are needed for entrepreneurs to function effectively in homestay operations. Thus, success in entrepreneurship mostly depends on entrepreneurial competences which should be developed in order to achieve a high level of performance in homestay operations while training programmes should be introduced to develop them. Entrepreneurial orientation is also positively linked to the performance of homestays and therefore makes a positive contribution as well, while a deficiency can be an enormous challenge in CBT.

This study has shown help for the growth of CBT in Sri Lanka by developing productive entrepreneurs in the tourism industry. The findings can be used to develop entrepreneurs in the homestay tourism sector as this sector is important for developing entrepreneurs by utilizing their orientation and competences in their local communities to make a considerable contribution to the Sri Lankan economy. The research has attempted to fill a gap in theory and make a significant addition to the existing body of knowledge in the field of entrepreneurship development within the Sri Lankan context. The researchers would recommend similar studies to be carried out in different counties to test the competences and orientation of entrepreneurs in CBT. 


\title{
PRZEDSIĘBIORCZOŚĆ W TURYSTYCE OPARTEJ NA SPOŁECZNOŚCIACH LOKALNYCH SRI LANKI
}

\author{
Indika Priyantha Kaluarachchige ${ }^{\text {(DD }}$, Mohd Shukri Ab Yajid ${ }^{\text {(iD), }}$ \\ Ali Khatibic (iD, S.M. Ferdous Azam ${ }^{\mathrm{d}}$
}

\footnotetext{
a Uniwersytet Zarządzania i Nauki, Malezja; Kolegium Uniwersyteckie w Matarze, Sri Lanka, Wydział Studiów Menedżerskich; http://orcid.org/0000-0002-7489-5279; e-mail: indikapri@gmail.com

${ }^{\mathrm{b}}$ Uniwersytet Zarządzania i Nauki, Malezja; https://orcid.org/0000-0001-5688-4392; e-mail: shukri@msu.edu.my

c Uniwersytet Zarządzania i Nauki, Malezja, Centrum Doktoranckie; https://orcid.org/0000-0002-2531-7720; e-mail: alik@msu.edu.my

${ }^{d}$ Uniwersytet Zarządzania i Nauki, Malezja, Centrum Doktoranckie; https://orcid.org/0000-0002-0001-3595; e-mail: drferdous@msu.edu.my
}

Sposób cytowania (styl APA): Kaluarachchige, I.P., Yajid, M.S.A., Khatibi, A., Azam, S.M.F. (2021). Entrepreneurship in community-based tourism in Sri Lanka. Turyzm/Tourism, 31 (2), 87-101. https://doi.org/10.18778/0867-5856.31.2.05

\begin{abstract}
ABSTRAKT
Artykuł jest poświęcony zagadnieniu przedsiębiorczości w turystyce opartej na społecznościach lokalnych (CBT - community-based tourism) Sri Lanki. Autorzy omówili znaczenie kompetencji przedsiębiorczych oraz orientacji na jakość w przypadku pobytów oferowanych w domach rodzin goszczących, choć w większości z nich nie jest ona zadowalająca. Wprawdzie najnowsze badania wykazały, że turystyka oparta na takich pobytach nie jest efektywna, ale mimo to została ona uznana za sektor rozwojowy dla przedsiębiorców, który może wnosić znaczący wkład w gospodarkę Sri Lanki. Celem pracy jest wzmocnienie pozycji CBT poprzez pokazanie jak można stać się produktywnym przedsiębiorcą w tym sektorze. Podstawą do rozważań jest teoria podejścia zasobowego (resource-based view - RBV) - w ramach CBT zarejestrowanych jest 645 jednostek świadczących usługę pobytów domowych. Próba badawcza objęła 252 przedsiębiorców. Do analizy danych zastosowano modele równań strukturalnych (structural equation modeling -SEM). Wyniki badań świadczą o tym, że zarówno kompetencje, jak i orientacja przedsiębiorcza znacząco wpływają na działanie przedsiębiorcy CBT. Opisywane badanie pomoże rozwinąć turystykę opartą na społeczności lokalnej jako część krajowego sektora turystycznego.
\end{abstract}

\section{SŁOWA KLUCZOWE}

kompetencje przedsiębiorcze, orientacja przedsiębiorcza, turystyka oparta na społeczności lokalnej

\section{INFORMACJE O ARTYKULE}

Przyjęto:

8 września 2021 r.

Zaakceptowano:

21 października $2021 \mathrm{r}$.

Opublikowano:

21 grudnia $2021 \mathrm{r}$.

\section{WSTĘP}

W ostatnim czasie na całym świecie nastąpiło upowszechnienie się przedsiębiorczości, która wraz z przedsiębiorcami jest siłą napędową działalności gospodarczej w każdym kraju (Vashishtha, 2021). Przedsiębiorczość jest praktyką wprowadzania innowacyjnych produktów i usług poprzez tworzenie nowych firm lub rozwijanie już istniejących i kontynuowanie ich działalności (Sajeena, 2020). W ostatnich dekadach nastąpił gwałtowny rozwój przedsiębiorczości na całym świecie (Catalin, George, Razvan, 2017). Większość krajów polega na działaniu firm, chcąc stymulować i rozwijać swoją gospodarkę (Hallam, Dosamantes, Zanella, 2017). Przedsiębiorczość jest więc istotna, ponieważ warunkuje wzrost i przyspieszenie produktywności przedsięwzięć biznesowych (Sok, Snell, Lee, Sok, 2017).
Przedsiębiorczość to zdolność i gotowość do organizowania i rozwijania przedsięwzięcia biznesowego oraz doprowadzania do jego sukcesu w celu osiągnięcia zysku, przy uwzględnieniu wszelkiego ryzyka (Business Dictionary, 2020). Kompetencje przedsiębiorcy można określić jako zespół umiejętności powiązanych z produktywną przedsiębiorczością i kojarzonych zazwyczaj z innowacyjnościa, zdolnością przetrwania oraz rozwojem firmy (Carayannopoulos, 2017). Orientacja przedsiębiorcza uważana jest za umiejętność kontrolowania działalności firmy poprzez wiążące się z tym podejmowanie ryzyka, wprowadzanie innowacji oraz proaktywność (Dada, Fogg, 2016; De Clercq, Dimov, Thongpapanl, 2015; Gupta, Batra, 2015; Reijonen, Tammi, Saastamoinen, 2015).

Przedsiębiorczość zawsze była cenioną praktyką w przemyśle turystycznym. Jest to jeden z głównych 
obszarów, w których możliwości rozwojowe są nieograniczone, a turystyka ma ogromny potencjał (Sikari, 2018). Udział społeczności lokalnej ma pozytywny wpływ na sukces przedsiębiorców oferujących gościnę u siebie (Yong, Hassan, 2017). Aby zapewnić sobie powodzenie w przyszłości, przedsiębiorcy, którzy sami należą do danej społeczności i występują w roli osób oferujących gościnę, muszą wykazać się kompetencjami przedsiębiorczymi (Kayat, Zainuddin, Ramli, Kasim, 2016). Są one bardzo istotne (Witchayakawin, Aziz, Mahomed, Abdullah, 2020).

Turystyka oparta na społeczności lokalnej (CBT) umożliwia jej członkom, którzy pragną zaangażować się w działalność turystyczna, udział np. w prowadzeniu usług noclegowych (Junaid, Salam, Salim, 2019). Pobyty domowe to program CBT, który zapewnia odwiedzającym ekscytujące doświadczenia w otoczeniu lokalnej kultury jako alternatywny produkt turystyczny. Stały się one popularne w wielu krajach dzięki doświadczeniom turystów, którzy chcą wchodzić w interakcję z lokalną społecznościa, jej systemem społecznym, stylem życia, językiem, ludźmi oraz podnosić status socjoekonomiczny za pośrednictwem przemysłu turystycznego (Wijesundara, Gnanapala, 2015).

Sri Lanka powinna wspierać przedsiębiorczość poprzez rozwój kultury przedsiębiorczości. Innowacyjność i kreatywność będą z pewnością odgrywać tutaj ważną rolę w osiąganiu celów zorientowanych na rozwój, przy konkurencyjnej przewadze nad innymi krajami.

Podczas kształtowania kultury przedsiębiorczości istotne jest, aby potencjalni inwestorzy i przedsiębiorcy inicjowali i kontynuowali działalność gospodarczą na Sri Lance, ponieważ może to być dla nich prawdziwą zachętą. Zatem Sri Lanka powinna wytworzyć kulturę przedsiębiorczości, która jest częścią życia ludzi mieszkających w tym kraju (Perera, 2018). Oferowanie pobytów turystycznych w domach prywatnych ma ogromny potencjał jako operacja biznesowa w przypadku lokalnych firm (Ranasinghe, 2015). Departament Rozwoju Turystyki Sri Lanki podjął działania umożliwiające członkom lokalnej społeczności wykorzystanie swego doświadczenia, aby mogli stać się przedsiębiorcami (Sriyani, 2018). Zaprezentowane w niniejszym tekście badania mają na celu wsparcie przedsiębiorczości opartej na miejscowej społeczności na Sri Lance.

\section{Problem badawczy}

Jak wykazały ostatnie badania przeprowadzone na Sri Lance (Ranasinghe, 2015; Sriyani, 2018; Wijesundara, Gnanapala, 2015), większość gospodarstw oferujących gościnę domową nie odnosi sukcesu. Sriyani
(2018) podkreśliła, że pomimo popularności pobytów domowych, ich szanse na sukces i przetrwanie osłabia wiele poważnych problemów. Wijesundara i Gnanapala (2015) stwierdzili, że turystyka, w ramach której podróżni mieszkają w domach prywatnych, nie funkcjonuje dobrze jako alternatywny produkt turystyczny.

Biorąc pod uwage najnowsze badania Croosa, Kumara, Nawarathne'a i Idroosa (2020) dotyczące Sri Lanki, należy stwierdzić, że możliwości rozwoju CBT są ogromne, jeśli pokona się pewne przeszkody. Istnieje wiele szans (Madushi, Ranasinghe, Sammani, 2020; Ranasinghe, Damunupola, Kumara, Sammani, 2020; Sumithra, 2020), ale również sporo wyzwań i problemów (Jayasundara, Tennakoon, Wijesundara, 2020).

Aby odnosić sukcesy jako przedsiębiorca, trzeba rozwijać kompetencje przedsiębiorcze, jako że są one podstawą powodzenia małych firm (Sajeena, 2020). Ważny dodatek do ich działania stanowi niewątpliwie orientacja przedsiębiorców (Alalawi, 2020).

Badania kompetencji i orientacji w przedsiębiorczości były niezależnie ukierunkowane na działalność małych firm, ale istnieje kilka prac naukowych, które skupiają się na teoretycznej fuzji orientacji i kompetencji przedsiębiorczych (Kaluarachchige, Yajid, Khatibi, Azam, 2021a). Hashim, Raza i Minai (2018) stwierdzili, że związek między kompetencjami przedsiębiorców a sukcesem małych firm jest wątpliwy, ponieważ wyniki badań poświęconych tej zależności nie są zbieżne. Mitchelmore i Rowley (2013) określiły je jako podstawę zaawansowanych studiów kompetencji przedsiębiorców, które mają wpływ na osiągnięcia małych firm. Badania empiryczne właściwie nie objęły roli orientacji przedsiębiorczej w organizacji usługowej, a odkrycia empiryczne wciąż nie pozwalają na powiązanie zmiennych kierunku przedsiębiorczości z przedsiębiorczym działaniem, zwłaszcza w analizach dotyczących pobytów domowych (Ahmad, Supian, Muhammad Yunus, Tanius, Ishak, 2019).

Co więcej, prawdopodobnie istnieje luka badawcza w wiedzy dotyczącej kompetencji przedsiębiorców (Yusuff, Bakar, Ahmad, 2016). Konieczne jest zatem przeprowadzenie dalszych badań nad związkiem między kompetencjami przedsiębiorczymi a sukcesem (Hashim, Raza, Minai, 2018). Działalność małych firm jest bardzo ważna dla osiągnięcia sukcesu gospodarczego, przede wszystkim w krajach rozwijających się, ale studia nad przedsiębiorczością są ograniczone (Coder, Peake, Spiller, 2017; Hyder, Lussier, 2016). Konieczne jest więc sporządzanie analiz w małych firmach (Hashim, Raza, Minai, 2018). Badania powiązane należy przeprowadzać w krajach rozwijających się. Powinny być one powtarzane, by można było ostatecznie potwierdzić uzyskane wyniki (Ibrahim, Abu, 2020). 


\section{PRZEgląd Literatury}

Przedsiębiorczość to praktyka zakładania nowej firmy $\mathrm{w}$ celu produkowania i sprzedawania innowacyjnych, oryginalnych lub wiodących towarów lub usług, a małe i średnie przedsiębiorstwa (SME) to szansa dla nowych przedsiębiorców (Kaluarachchige, Yajid, Khatibi, Azam, 2021a). Przedsiębiorczość postrzegana jest jako główna inicjatywa wzrostu, która prowadzi do tworzenia nowych miejsc pracy, a także do rozwoju gospodarczego, innowacyjności i konkurencyjności (Sajeena, 2020). Staje się ona głównym pojęciem $\mathrm{w}$ ramach zrównoważonego rozwoju gospodarczego $\mathrm{w}$ dzisiejszym złożonym i dynamicznym świecie biznesu (Akbar, Bon, Wadood, 2020). W literaturze naukowej poświęconej przedsiębiorczości podkreśla się rolę przedsiębiorców w osiąganiu sukcesu przez firmy, zwłaszcza małe (Tahseen, Ramayah, 2015). Wpływ przedsiębiorczości na sukces biznesowy został zaakcentowany w różnych publikacjach (Monteiro, Rua, Soares, 2019), ale nadal potrzeba wielu dowodów empirycznych, aby w pełni zrozumieć jej istotę (Rauch, 2015). Hyder i Lussier (2016) twierdza, że należy przede wszystkim skupiać się na produktywności i wyzwaniach w krajach rozwijających się.

U podstaw niniejszego badania leży teoria RBV (resource-based view), w której nacisk kładziony jest na wagę zasobów firmy jako głównego czynnika przewagi konkurencyjnej i lepszych wyników. W podejściu RBV zasoby firmy mają cztery wymiary, decydujące o jej zrównoważonej przewadze - zarówno te materialne, jak i niematerialne z natury (Wernerfelt, 1984) powinny być one cenne, rzadkie, niepowtarzalne i nie do zastąpienia (Barney, 1991). Zgodnie z teorią RBV główne atrybuty kapitału ludzkiego, takie jak kompetencje, są uznawane za zasoby niematerialne (Barney, 1991). Cechy, możliwości i umiejętności mogą się przekształcić w zespół wewnętrznych, unikatowych zasobów, którym małe firmy muszą zaufać (Lerner, Almor, 2002). W kontekście małych firm, orientacji i kompetencji przedsiębiorczych zasoby te to rzadko spotykane umiejętności zarządzania, wykorzystywane w celu osiągnięcia wyjątkowych wyników przedsiębiorstwa.

Konstrukt kompetencji przedsiębiorczych charakteryzują możliwości, stosunki strategiczne i techniczne, jak również 12 uznanych kompetencji konceptualnych (Man, Thomas, Lau, Chan, 2002): podejmowanie ryzyka, strategia, kompetencje techniczne, zaangażowanie, kompetencje osobiste, możliwości, uczenie się, wiedza, relacje, podejmowanie decyzji, organizowanie i odpowiedzialność społeczna. Man (2001) odkrył również klastry kompetencji, takich jak: możliwości, uczenie się, nawiązywanie relacji, zaangażowanie oraz zdolności analityczne, strategiczne, konceptualne, innowacyjne, ludzkie, organizacyjne, operacyjne i osobiste. Później
Ahmad (2007) dodał do klastrów wprowadzonych przez Mana (2001) cztery kolejne obszary: etyczny, techniczny, rodzinny i odpowiedzialność społeczna, oraz podzielił kompetencje konceptualne na innowacyjne i analityczne.

Orientację przedsiębiorczą można określić jako strategiczną pozycję firmy, która prezentuje postawę proaktywną innowacyjną i świadczącą o skłonności do podejmowania ryzyka, w całości lub w pojedynczym wymiarze (Wales, 2015). Mówi się, że orientacja przedsiębiorcza jest zapalnikiem innowacyjnego modelu biznesowego w odniesieniu do aspektów, wspierających zmiany (innowacyjne i proaktywne) oraz trendy decyzyjne w sytuacji wymiernego ryzyka (Bouncken, Lehman, Fellnhofer, 2016). Symbolizuje ona zachowanie osób poszukujących możliwości w biznesie słynącym z proaktywności, innowacyjności i podejmowania ryzyka (Dada, Fogg, 2016; De Clercq, Dimov, Thongpapanl, 2015; Reijonen, Tammi, Saastamoinen, 2015). Według Gautama (2016) orientację przedsiębiorców charakteryzuje pięć wymiarów: innowacyjność, proaktywność, autonomia, konkurencyjna agresja i podejmowanie ryzyka. Co więcej, Haider, Asad i Fatima (2017) podkreślili, że orientacja przedsiębiorców opisana jest przez trzy wymiary: proaktywność, podejmowanie ryzyka i innowacyjność. Fatoki i Oni (2014) również oceniali orientację przedsiębiorcza, stosując te trzy elementy: innowacyjność, podejmowanie ryzyka i proaktywność.

Każdy ma swoją indywidualna, specyficzną orientację i kompetencje przedsiębiorcze, za którymi nie jest łatwo nadążyć konkurentom (Tehseen, Ramayah, 2015). Istnieje związek między nimi a wynikami firmy (Bahari, Yunus, Jabar, 2017).

Wiadomo, że kompetencje przedsiębiorcze to zestaw umiejętności związanych z udaną działalnością gospodarczą (Kaluarachchige, Yajid, Khatibi, Azam, 2021b). Umiejętności te są silnie powiązane z rozwojem i wzrostem małych przedsiębiorstw (Carayannopoulos, 2017). Grimmer, Miles, Byrom i Grimmer (2017) zbadali działalność małych firm zależnych od czynników strategicznych, ale odkryli, że najważniejsze są kompetencje przedsiębiorców. Jak twierdzą Peric, Grladinovic, Kropivsek i Greger (2017), kompetencje przedsiębiorcze mogą zwiększyć sukces firmy.

Kompetencje przedsiębiorcze odgrywają ważną rolę w rozwoju i przetrwaniu organizacji biznesowej / firmy (Khan, Ali, Jantan, Latiff, 2018). Niemniej jednak niewystarczające kompetencje w małej firmie mogą być przyczyną poważnych problemów i trudności w prowadzeniu działalności na wysokim poziomie (Pulka, Ramli, Mohamad, 2018). Kompetencje przedsiębiorców zostały uznane za bardzo istotny czynnik sukcesu - są niezbędne do przeprowadzenia transformacji organizacyjnej ich firmy (Mohsin, Halim, Ahmad, Farhana, 2017). W kapitale najistotniejszym dla przedsiębiorstwa 
najcenniejsze są właśnie kompetencje przedsiębiorcze (Sozuer, Altuntas, Semercioz, 2017; Tehseen, Ramayah, 2015).

Pozytywny wpływ kompetencji przedsiębiorczych na wyniki firmy był szeroko omawiany w literaturze przedmiotu (Farooq, Abideen, 2015; Tehseen, 2017). Ogólnie - według badań empirycznych - mają one wpływ na osiągnięcia małych i średnich przedsiębiorstw (SME) (Tehseen, Ramayah, 2015; Yusuff, Bakar, Ahmad, 2016).Wcześniejsze badania nad korelacją kompetencji i sukcesu firmy świadczą o istotnym związku (Nwachukwu, Chladkova, Zufan, 2017) i potwierdzają pozytywny wpływ tych pierwszych na powodzenie firmy (Kabir, Ibrahim, Shah, 2017). Istnieje wiele badań, które łączą kompetencje z działalnością i wynikami małych biznesów (Barazandeh, Parvizian, Alizadeh, Khosravi, 2015; Mitchelmore, Rowley, Shiu, 2014; Sarwoko, Surachman, Hadiwidjojo, 2013; Tehseen, Ramayah, 2015). Rozwijanie kompetencji jest konieczne zarówno do osiągnięcia sukcesu przez samego przedsiębiorce, jak i do rozwinięcia działalności małej firmy (Sajeena, 2020).

Istnieje potrzeba przeprowadzenia zaawansowanych badań nad kompetencjami przedsiębiorczymi, które wpływają na sukces SME (Mitchelmore, Rowley, 2013). Nadal istnieje luka w wiedzy na temat kompetencji (Yusuff, Bakar, Ahmad, 2016), zatem dodatkowe badania dotyczące związku między kompetencjami przedsiębiorców a sukcesem małych firm są niezbędne (Hashim, Raza, Minai, 2018).

Wpływ orientacji przedsiębiorców na działalność małych firm był zgłębiany w wielu badaniach (Monteiro, Soares, Rua, 2019). Orientacja przedsiębiorcza jest pojęciem organizacyjnym, często stosowanym w badaniach nad przedsiębiorczością (Kaluarachchige, Yajid, Khatibi, Azam, 2021b). Wielu badaczy odkryło pozytywny wpływ tej orientacji na wyniki małych firm (Lomberg, Urbig, Stockmann, Marino, Dickson, 2016). Lisboa, Skarmeas i Saridakis (2016) przeanalizowali wiele wcześniejszych studiów i odkryli, że połączenie cech może zostać wykorzystane do badania ich wpływu na wyniki. Również Ahmad, Supian, Muhammad Yunus, Tanius i Ishak (2019) doszli do wniosku, że z wcześniejszych badań naukowych wynika bezpośrednie powiązanie orientacji przedsiębiorcy z działaniem firmy.

Orientacja przedsiębiorcza ma zazwyczaj duży wpływ na działalność firmy (Caseiro, Coelho, 2018). Radulovich, Javalgi i Scherer (2018) odkryli, że wpływa ona bezpośrednio na sukces małych firm (Musthofa, Wahyudi, Farida, Ngatno, 2017). Lee i Chu (2017) zbadali, do jakiego stopnia ma ona pozytywny wpływ na wyniki firmy, podczas gdy Matchaba-Hove, Farrington i Sharp (2015) stwierdzili, że istnieje bezpośrednie powiązanie między orientacją przedsiębiorczą a sukcesem w biznesie. Rola orientacji przedsiębiorców $\mathrm{w}$ małych firmach została powszechnie uznana w lite- raturze (Brouthers, Nakos, Dimitratos, 2015; Gupta, Batra, 2015).

Również najnowsze badania świadczą o tym, że orientacja przedsiębiorcza pozytywnie wpływa na działalność małych firm (Alalawi, 2020; Igweh, Stephen, 2019; Oni, Agbobli, Iwu, 2019). Na jej podstawie można przewidzieć ich wyniki (Fitriati, Purwana, Buchdadi, Subagja, 2020; Khan, Xuele, Atlas, Khan, 2019; Oni, Agbobli, Iwu, 2019; Sulistyo, Ayuni, 2020).

Potrzebne są pogłębiona analiza wymiaru orientacji przedsiębiorczej (Putniņš, Sauka, 2019) oraz dalsze badania (Solikahan, Mohammad, 2019). Ibrahim i Abu (2020) wspominaja że powinno się podjąć podobne badania, aby potwierdzić wyniki. Dalsze studia są niezbędne, aby ustalić charakter zależności między orientacją przedsiębiorczą a działalnością firmy oraz aspekty, które mogą wpływać na ten związek (Akbar, Bon, Wadood, 2020).

\section{METODYKA BADAŃ}

Model koncepcyjny dla tego badania został skonstruowany na podstawie podstawowych zasad teorii RBV. Stworzono rzetelne ramy badania naukowego, a wyniki zostały w dużym stopniu zweryfikowane (Hashim, Raza, Minai, 2018). Zgodnie z informacjami zawartymi w literaturze przedmiotu kompetencje i orientacja przedsiębiorcza umożliwiają przewidywanie wyników działalności przedsiębiorcy. Kompetencje strategiczne, zaangażowanie, organizacja, umiejętność wykorzystania możliwości, nawiązywania relacji oraz kompetencje koncepcyjne to główne wymiary kompetencji przedsiębiorczych. Natomiast główne aspekty orientacji przedsiębiorczej to: proaktywność, podejmowanie ryzyka i innowacyjność. Czynniki finansowe i strategiczne to z kolei wymiary działalności przedsiębiorcy.

Podniesienie kompetencji przedsiębiorczych będzie miało bezpośredni wpływ na lepszą działalność firmy (Sarwoko, Nurfarida, 2018). Nwachukwu, Chladkova i Zufan (2017) wskazuja, że mają one ogromne znaczenie dla sukcesu firmy, a wcześniejsze badania sugerują pozytywną zależność. W ten sposób wysunięto pierwszą hipotezę: „H1: Kompetencje przedsiębiorcze znacząco wpływają na wyniki firmy". Poprawa orientacji przedsiębiorczej determinuje wyniki firmy (Sarwoko, Nurfarida, 2018). Ogólnie rzecz ujmujacc, orientacja ta ma pozytywny wpływ na działanie organizacyjne (Caseiro, Coelho, 2018). Podobnie Radulovich, Javalgi i Scherer (2018) wykazali, że orientacja przedsiębiorcza bezpośrednio wpływa na działalność małych i średnich firm. W ten sposób sformułowano drugą hipotezę: „H2: Orientacja przedsiębiorcza znacząco wpływa na działanie”.

Niniejsze badanie oparte jest na podejściu dedukcyjnym, autorzy zastosowali przede wszystkim pozy- 
tywny paradygmat badawczy. Dane zostały zebrane z pierwotnych źródeł, a podstawową metodę badawczą stanowiły badania ankietowe. Głównym narzędziem badawczym wykorzystanym do zbierania danych ilościowych był kwestionariusz ustrukturyzowany. Prawidłowo ustalono prawdziwość i rzetelność, a za jednostkę do analizy przyjęto pojedynczego przedsiębiorcę.

Rozpatrzono 252 przypadki przedsiębiorców CBT, oferujących pobyty domowe, spośród 645 gospodarstw zarejestrowanych przez Departament Rozwoju Turystyki Sri Lanki. Dane zbierane były ze wszystkich dzielnic. Zastosowano przy tym metodę warstwowego, losowego doboru nieproporcjonalnego. Kwestionariusz wysłano do 302 podmiotów, uzyskano 261 ankiet zwrotnych, z czego 9 pominięto. Udział odpowiedzi wynosił 83\%. Większość respondentów miała 35-45 lat i wykształcenie średnie.

\section{ANALIZA DANYCH}

W badaniu zastosowano modele równań strukturalnych (SEM), w dwóch fazach - model pomiarów i model strukturalny. Model pomiarów (zob. rysunek 1) został opracowany za pomocą kombinacji 24 elementów odnoszących się do ostatecznych wyników konfirmacyjnej analizy czynnikowej (Confirmatory Factor Analysis - CFA). Są to: kompetencje przedsiębiorcze (EC) - 9 elementów, orientacja przedsiębiorcza (EO) - 9 elementów, wyniki przedsiębiorcy (EP) - 6 elementów. Zalecane wartości wskaźników dopasowania i statystykę modelu zaprezentowano w tabeli 1.

Wskaźniki chi-kwadrat, CFI (Comparative Fit Index) i RMSEA (Root Mean Square Error Of Approximation) są zbliżone do wartości rekomendowanych i oceniane jako dobrze dopasowane. W związku z tym 24 elementy w ostatecznym modelu pomiarów odpowiadają danym w wystarczającym stopniu (rysunek 1). Dzięki temu wiadomo, że wszystkie elementy wywierają porównywalny wpływ na każdy konstrukt. Zmienne w modelu pomiarów zaprezentowano w tabeli 2.

Ta część wyjaśnia walidację modelu pomiarów (pierwszy etap). Model strukturalny może więc być oceniany i prezentowany $\mathrm{w}$ drugiej fazie modelowania równania strukturalnego (Hair, Black, Babin, Anderson,
Tatham, 2006; Kline 2005). Byrne (1989) twierdzi, że celem tworzenia modelu strukturalnego jest wyjaśnienie związków (bezpośrednich i pośrednich) z innymi konstruktami. Ostateczny model strukturalny został pokazany na rysunku 2 (zob. s. 98).

Wynik skojarzenia zmiennych (wagi regresji) w finalnym modelu strukturalnym zaprezentowano $\mathrm{w}$ tabeli 3 .

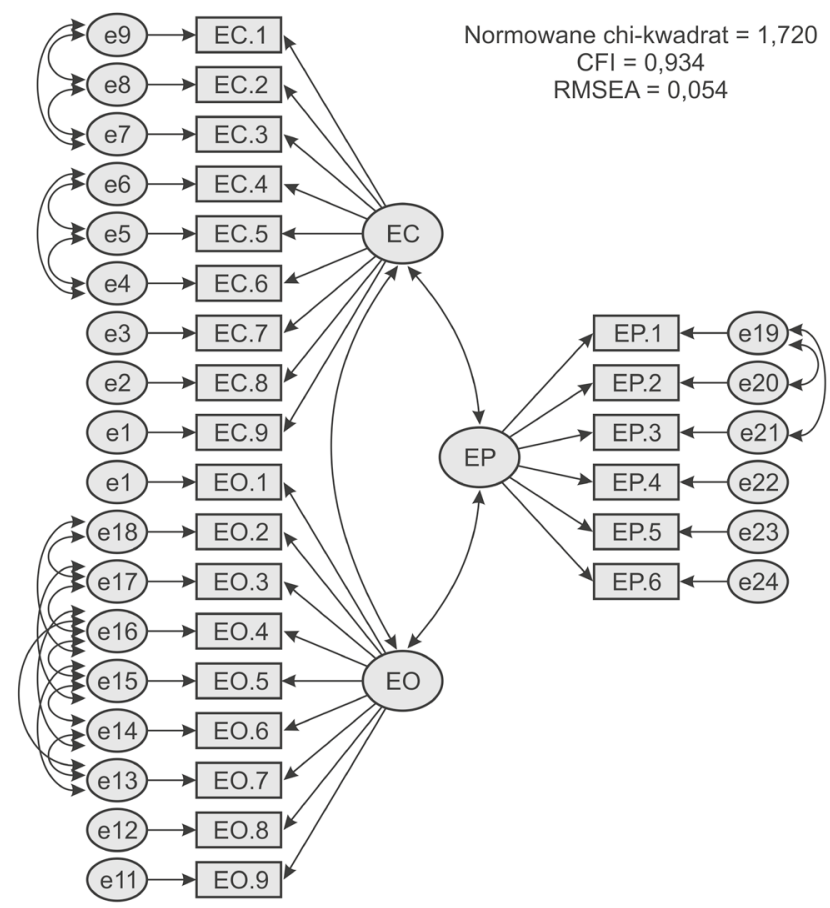

Rysunek 1. Model pomiarów Źródło: opracowanie własne

Tabela 2. Zmienne w modelu pomiarów

\begin{tabular}{|l|c|c|c|c|c|}
\cline { 2 - 6 } \multicolumn{1}{c|}{} & Przybliżenie & S.E. & C.R. & P & Korelacja \\
\hline E.C. $\leftrightarrow$ E.P. & 0,308 & 0,061 & 5,064 & $* * *$ &, 411 \\
\hline E.O. $\leftrightarrow$ E.P. & 0,223 & 0,054 & 4,150 & $* * *$ &, 303 \\
\hline
\end{tabular}

Źródło: opracowanie własne.

Tabela 3. Wagi regresji w modelu strukturalnym

\begin{tabular}{|c|c|c|c|c|c|}
\cline { 2 - 6 } \multicolumn{1}{c|}{} & $\begin{array}{c}\text { Niestandardowe } \\
\text { oszacowanie }\end{array}$ & S.E. & C.R. & P & $\begin{array}{c}\text { Standardowe } \\
\text { oszacowanie }\end{array}$ \\
\hline E.P. $\leftarrow$ E.C. & 0,236 & 0,045 & 5,293 & $* * *$ & 0,357 \\
\hline E.O. $\leftarrow$ E.P. & 0,175 & 0,041 & 4,247 & $* * *$ & 0,258 \\
\hline
\end{tabular}

Źródło: opracowanie własne.

Tabela 1. Wyniki modelu pomiarów

\begin{tabular}{|l|c|c|c|}
\hline Wskaźniki dopasowania (dokładność dopasowania) & Akceptowane wartości (wartość graniczna) & Wynik & Ewaluacja modelu \\
\hline Chi-kwadrat/df & $<3$ & 1,720 & Dobre dopasowanie \\
\hline CFI & $>0,9$ & 0,934 & Dobre dopasowanie \\
\hline RMSEA & $<0,08$ & 0,054 & Dobre dopasowanie \\
\hline
\end{tabular}

Źródło: opracowanie własne. 


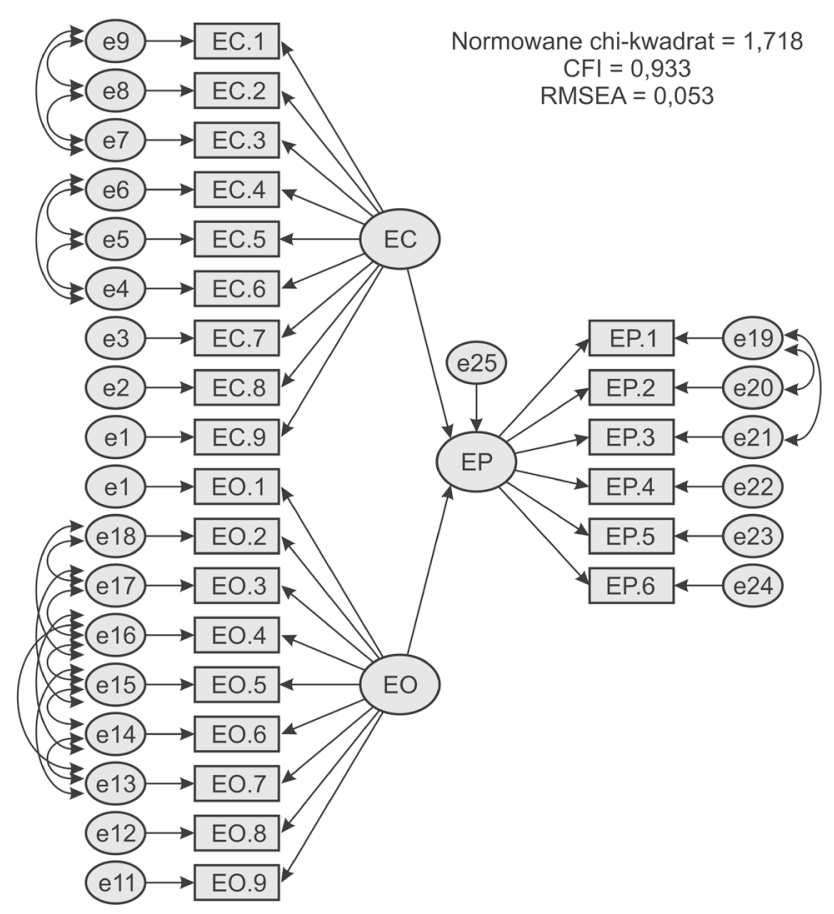

Rysunek 2. Model strukturalny

Źródło: opracowanie własne

Wyniki połączeń między zmiennymi w ostatecznym modelu strukturalnym zaprezentowane zostały w tabeli, z której wynika, że nastąpił istotny $(\mathrm{P}<0,01)$ efekt dodatni pomiędzy kompetencjami i orientacją w przedsiębiorczości a działaniem przedsiębiorcy. Najważniejszy wpływ na to działanie mają kompetencje przedsiębiorcze w CBT. Zwiększanie kompetencji (strategicznych, zaangażowania, organizacyjnych, wykorzystywania możliwości, tworzenia relacji itd.) jest ważne dla rozwoju działalności. Proaktywność, podejmowanie ryzyka i innowacyjność są jednak ważnymi czynnikami orientacji przedsiębiorczych.

\section{WNIOSKI}

Badanie dotyczyło przedsiębiorczości w CBT na Sri Lance. Autorzy przeanalizowali wpływ kompetencji i orientacji przedsiębiorczej na zachowania przedsiębiorców. W artykule wyjaśniono obecną sytuację oraz wysunięto sugestie dotyczące dalszego rozwoju przedsiębiorczości. Ostatnie badania przeprowadzone w kontekście Sri Lanki wykazuja, że większość gospodarstw udzielających gościny nie odnosi sukcesu w ramach turystyki opartej na lokalnej społeczności (CBT), a turystyka, w ramach której oferowane są pobyty domowe jako zastępczy produkt turystyczny, nie funkcjonuje dobrze.

Wyniki badań świadczą o tym, że zarówno kompetencje przedsiębiorcze, jak i orientacja znacząco wpływają na efekty działalności w CBT, przy czym kompetencje są ważniejsze niż orientacja. Biorąc pod uwage kontekst, jest to pierwsze badanie empiryczne uwzględniające jednocześnie zarówno kompetencje, jak i orientację przedsiębiorców w pojedynczym studium oceniającym wyniki przedsiębiorców. Pobyty domowe mogą przyczynić się do rozwoju przedsiębiorców poprzez CBT, dzięki wykorzystaniu ich orientacji i kompetencjom w lokalnych społecznościach w celu rozwijania gospodarki Sri Lanki.

Zwiększanie kompetencji jest niezwykle ważne dla przedsiębiorców, by mogli zacząć odnosić sukcesy, ponieważ mają oni wpływ na rozwój sektora turystyki opartej na gościnności domowej. Kompetencje są niezbędne, żeby przedsiębiorcy efektywnie funkcjonowali w ramach udzielania gościny domowej. Sukces w przedsiębiorczości zależy zatem głównie od kompetencji, które należy rozwijać, by osiągnąć wysoki poziom $w$ ramach tego typu działalności. Powinno się wprowadzić programy szkoleniowe mające na celu rozwijanie owych kompetencji. Orientacja przedsiębiorcza jest również pozytywnie skorelowana z działalnością związaną z gościnnością domową. Dlatego to ona w dużej mierze sprzyja osiągnięciu sukcesu, podczas gdy jej brak może stanowić poważne wyzwanie w CBT.

Omówione w niniejszym artykule badanie świadczy o wsparciu dla rozwoju CBT na Sri Lance dzięki produktywnym przedsiębiorcom w sektorze turystycznym.

Wyniki mogą wpływać na rozwój przedsiębiorców w sektorze turystyki opartej na gościnności domowej. Ten sektor odgrywa ważną rolę we wspomnianym procesie ze względu na możliwość wykorzystywania orientacji i kompetencji przedsiębiorców w ich lokalnych społecznościach, a tym samym ma duże znaczenie dla rozwoju całej gospodarki Sri Lanki.

Celem badania było wypełnienie luki w teorii i poszerzenie istniejącej wiedzy w zakresie rozwoju przedsiębiorczości w gospodarce Sri Lanki. Badacze rekomendują przeprowadzenie podobnych badań na temat kompetencji i orientacji przedsiębiorców w CBT w różnych krajach.

\section{REFERENCES/BIBLIOGRAFIA}

Ahmad, A., Supian, K., Muhammad Yunus, I.F., Tanius, E., Ishak, B. (2019). Entrepreneurial orientation and hospitality performance: The mediating effect of market orientation. International Journal of Accounting, Finance and Business (IJAFB), 4 (19), 61-71.

Ahmad, N.H. (2007). A cross cultural study of entrepreneurial competences and entrepreneurial success in SMEs in Australia and Malaysia. PhD dissertation. The University of Adelaide, Australia.

Akbar, F., Bon, A.B., Wadood, F. (2020). Open innovation mediates the relationship between entrepreneurial orientation and firm performance: A preliminary survey. Proceedings of the International Conference on Industrial Engineering and Operations Management Dubai, 3136-3150. 
Alalawi, G.N.S. (2020). The influence of entrepreneurship orientation on omani smes' performance. Doctoral dissertation. University of Plymouth.

Bahari, N., Yunus, A.R., Jabar, J. (2017). Effective success factor of malaysian smes firm performance influence by entrepreneur personal characteristics, entrepreneurial orientation and government support program. The Social Sciences, 12 (7), 1157-1162.

Barazandeh, M., Parvizian, K., Alizadeh, M., Khosravi, S. (2015). Investigating the effect of entrepreneurial competences on business performance among early stage entrepreneurs Global Entrepreneurship Monitor (GEM 2010 survey data). Journal of Global Entrepreneurship Research, 5 (1), 18. https://doi. org/10.1186/s40497-015-0037-4

Barney, J.B. (1991). Firm resources and sustained competitive advantage. Journal of Management, 17 (1), 99-120. https://doi. org/10.1177/014920639101700108

Bouncken, R.B., Lehman, C., Fellnhofer, K. (2016). The role of entrepreneurial orientation and modularity for business model innovation in service company. International Journal Entrepreneurial Venturing, 8 (3), 237-260. https://doi.org/10.1504/ IJEV.2016.078973

Brouthers, K.D., Nakos, G., Dimitratos, P. (2015). SME entrepreneurial orientation, international performance, and the moderating role of strategic alliances. Entrepreneurship: Theory and Practice, 39 (5), 1161-1187. https://doi.org/10.1111/etap.12101

Business Dictionary (2020). Retrieved from: http://www.businessdictionary.com/definition/entrepreneurship.html (30.03.2020).

Byrne, B.M. (1989). A primer of LISREL: Basic applications and programming for confirmatory factor analytic model. New York: Springer-Verlag. https://doi.org/10.1007/978-1-4613-8885-2

Carayannopoulos, S. (2017). Small, young firm flexibility and performance in the context of disruptive innovations. International Journal of Entrepreneurship and Innovation Management, 21 (1-2), 105-118. https://doi.org/10.1504/IJEIM.2017.081467

Caseiro, N., Coelho, A. (2018). Business intelligence and competitiveness: The mediating role of entrepreneurial orientation. Competitiveness Review: An International Business Journal, 28 (2), 213-226. https://doi.org/10.1108/CR-09-2016-0054

Catalin, G., George, T.S., Razvan, P. (2017). Entrepreneurship in the world: The analysis of the global entrepreneurship index in the period 2015-2017. "Ovidius" University Annals, Economic Sciences Series, 17 (2), 14-18.

Coder, L., Peake, W., Spiller, S. (2017). Do high performance work systems pay for small firms? An intellectual capital building perspective. Journal of Small Business Strategy, 27 (2), 13-35.

Croos, J.T.T., Kumara, P.H.T., Nawarathne, A.M.D.B., Idroos, A.A. (2020). An analysis of barriers and opportunities of communitybased tourism. Proceedings of the International Research Conference, Uva Wellassa University, Sri Lanka. Retrieved from: http://www.uwu.ac.lk/wp-content/uploads/2020/proceeding_of_ircuwu2020.pdf (27.07.2020).

Dada, O., Fogg, E. (2016). Organizational learning, entrepreneurial orientation, and the role of university engagement in SMES. International Small Business Journal, 34 (1), 86-104. https://doi. org/10.1177/0266242614542852

De Clercq, D., Dimov, D., Thongpapanl, N.T. (2015). Structural and relational interdependence and entrepreneurial orientation in small and medium-sized enterprises: The mediating role of internal knowledge-sharing. International Small Business Journal 33 (5), 514-536. https://doi.org/10.1177/0266242613502801

Farooq, W., Abideen, Z.U. (2015). SMEs' preparedness to face economic crisis: a proposed framework for Malaysian SMEs, East West Journal of Business and Social Studies, 4 (2), 66-79.
Fatoki, O., Oni, O. (2014). The entrepreneurial orientation of immigrant entrepreneurs in South Africa. Mediterranean Journal of Social Sciences, 5 (20), 497-502. https://doi.org/10.5901/ mjss.2014.v5n20p497

Fitriati, T.K., Purwana, D., Buchdadi, A.D., Subagja, I.K. (2020). Entrepreneurial orientation and SME performance: Dynamic capabilities as mediation study on SMEs in Indonesia. International Conference on Humanities, Education, and Social Sciences (74-89). KnE Social Sciences. Retrieved from: https:// knepublishing.com/index.php/KnE-Social/article/view/7860 (30.11.2020). https://doi.org/10.18502/kss.v4i14.7860

Gautam, P.R. (2016). Entrepreneurial orientation and business performance of handicraft industry: A study of Nepalese handi craft enterprises. International Journal of Small Business and Entrepreneurship Research, 4 (2), 48-55.

Grimmer, L., Miles, M.P., Byrom, J., Grimmer, M. (2017). The impact of resources and strategic orientation on small retail firm performance. Journal of Small Business Management, 55 (S1), 7-26. https://doi.org/10.1111/jsbm.12368

Gupta, V.K., Batra, S. (2015). Entrepreneurial orientation and firm performance in Indian SMEs: Universal and contingency perspectives. International Small Business Journal, 34 (5), 1-23. https://doi.org/10.1177/0266242615577708

Haider, S.H., Asad, M., Fatima, M. (2017). Entrepreneurial orientation and business performance of manufacturing sector small and medium scale enterprises of Punjab Pakistan. European Business and Management, 3 (2), 21-28. https://doi. org/10.11648/j.ebm.20170302.12

Hair, J.F., Black, W.C., Babin, B.J., Anderson, R.E., Tatham, R.L. (2006). Multivariate Data Analysis. $6^{\text {th }}$ ed. Upper Saddle River, New Jersey: Prentice Hall.

Hallam, C., Dosamantes, C.A.D., Zanella, G. (2017). Culture and social capital network effects on the survival and performance of high-tech micro and small firms. Journal of Small Business and Enterprise Development, 25 (1), 81-106. https://doi.org/10.1108/ JSBED-05-2017-0161

Hashim, N.A.B., Raza, S., Minai, M.S. (2018). Relationship between entrepreneurial competences and small firm performance: Are dynamic capabilities the missing link. Academy of Strategic Management Journal. 17 (2), 1-10.

Hyder, S., Lussier, R.N. (2016). Why businesses succeed or fail: A study on small businesses in Pakistan. Journal of Entrepreneurship in Emerging Economies. 8 (1), 82-100. https:// doi.org/10.1108/JEEE-03-2015-0020

Ibrahim, A.U., Abu, M.M. (2020). Influence of entrepreneurial orientation on firms performance: Evidence from small and medium enterprises in Nigeria. International Journal of Economics and Financial Issues, 10 (2), 99-106. https://doi. org/10.32479/ijefi.9126

Igweh, F., Stephen, A. (2019). Effect of entrepreneurial roles on performance of SMEs: The Nigeria human resource perspective. International Journal of Business, Economics and Management, $3(1), 22-29$.

Jayasundara, H.M.M.T., Tennakoon, T.M.P.S.I., Wijesundara, W.G.S.R. (2020). A study on community involvement in tourism benefit sharing in Sri Lanka with special reference to Dambulla. Proceedings of the International Research Conference, Uva Wellassa University. Sri Lanka. Retrieved from: http://www. uwu.ac.lk/wp-content/uploads/2020/proceeding_of_ircuwu2020.pdf (30.07.2020).

Junaid, I., Salam, N., Salim, M.A.M. (2019). Developing homestay to support community-based tourism. Masyarakat, Kebudayaan dan Politik, 32 (4), 390-398. https://doi.org/10.20473/mkp. V32I42019.390-398

Kabir, M., Ibrahim, H.I., Shah, K.A.M. (2017). Entrepreneurial competence as determinant for success of female entrepreneurs 
in Nigeria. Indonesian Journal of Business and Entrepreneurship (IJBE), 3 (2), 143. https://doi.org/10.17358/ijbe.3.2.143

Kaluarachchige, I.P., Yajid, M.S.A., Khatibi, A., Azam, S.M.F. (2021a). Competences and orientation of entrepreneurs on dynamic capabilities towards organizational performance by considering external environment: Development of a conceptual model. Global Journal of Management and Business Research, 21 (1), 25-38.

Kaluarachchige, I.P., Yajid, M.S.A., Khatibi, A., Azam, S.M.F. (2021b). Review of literature on competences and orientation of entrepreneurs. International Journal of Advanced Scientific and Technical Research, 11 (1), 12-25. https://doi.org/10.26808/ rs.st.11v1.02

Kayat, K., Zainuddin, N.F.A., Ramli, R., Kasim, M.M. (2016). The perceived role of leadership and community support in the performance of community-based rural homestay programme in Malaysia. International Review of Management and Marketing, 6 (7), 145-149. https://doi.org/10.15405/epsbs.2016.08.80

Khan, K.U., Xuele, Z., Atlas, F., Khan, F. (2019). The impact of dominant logic and competitive intensity on SMEs performance: A case from China. Journal of Innovation and Knowledge, $4,1-11$.

Khan, G., Ali, M.H., Jantan, A.H.B., Latiff, A.R. (2018). Multicultural study of entrepreneurial competences and SMEs success in malaysian service industry: A conceptual model. Journal of Management Science and Business Intelligence, 3 (2), 44-49. https://doi.org/10.1016/j.jik.2018.10.001

Lee, T., Chu, W. (2017). The relationship between entrepreneurial orientation and firm performance: Influence of family governance. Journal of Family Business Strategy, 8 (1), 213-223. https:// doi.org/10.1016/j.jfbs.2017.09.002

Lerner, M., Almor, T. (2002). Relationship among strategic capabilities and the performance of women-owned SMEs. Journal of Small Business Management, 40 (2), 109-125. https://doi. org/10.1111/1540-627X.00044

Lisboa, A., Skarmeas, D., Saridakis, C. (2016). Entrepreneurial orientation pathways to performance: A fuzzy-set analysis. Journal of Business Research, 69 (4), 1319-1324. https://doi. org/10.1016/j.jbusres.2015.10.099

Lomberg, C., Urbig, D., Stockmann, C., Marino, L.D., Dickson, P.H. (2016). Entrepreneurial orientation: The dimensions' shared effects in explaining firm performance. Entrepreneurship Theory and Practice, 41 (6). https://doi.org/10.1111/etap.12237

Madushi, D.G.I., Ranasinghe, J.P.R.C., Sammani, U.G.O. (2020). Role of tourism as a community development tool with special reference to Patna, Deniyaya. Proceedings of the International Research Conference, Uva Wellassa University, Sri Lanka. Retrieved from: http://www.uwu.ac.lk/wp-content/uploads/2020/proceeding_of_ircuwu2020.pdf (30.07.2020).

Man, T.W.Y. (2001). Entrepreneurial competences and the performance of small and medium enterprises in the Hong Kong services sector. Doctoral dissertation. The Hong Kong Polytechnic University, Hong Kong.

Man, T.W.Y., Lau, T., Chan, K.F. (2002). The competitiveness of small and medium enterprises: A conceptualization with focus on entrepreneurial competences. Journal of Business Venturing 17 (2), 123-142. https://doi.org/10.1016/S0883-9026(00)00058-6

Matchaba-Hove, T., Farrington, S., Sharp, G. (2015). The entrepreneurial orientation-performance relationship: A South African small business perspective. The Southern African Journal of Entrepreneurship and Small Business Management, 7 (1), 36-68. https://doi.org/10.4102/sajesbm.v7i1.6

Mitchelmore, S., Rowley, J. (2013). Entrepreneurial competences of women entrepreneurs pursuing business growth. Journal of Small Business and Enterprise Development, 20 (1), 125-142. https://doi.org/10.1108/14626001311298448
Mitchelmore, S., Rowley, J., Shiu, E. (2014). Competences associated with growth of women-led SMEs. Journal of Small Business and Enterprise Development, 21 (4), 588-601. https:// doi.org/10.1108/JSBED-01-2012-0001

Mohsin, A.B.B.A., Halim, H.A., Ahmad, N.H., Farhana, N. (2017). Assessing the role of entrepreneurial competences on innovation performance: A partial least squares (PLS) approach. The Journal of Business Inquiry, 16 (1), 88-101.

Monteiro, A.P., Soares, A.M., Rua, O.L. (2019). Linking intangible resources and entrepreneurial orientation to export performance: The mediating effect of dynamic capabilities. Journal of Innovation and Knowledge, 4 (3), 179-187. https://doi. org/10.1016/j.jik.2019.04.001

Musthofa, Wahyudi, S., Farida, N., Ngatno. (2017). Effect of entrepreneurial orientation on business performance. International Journal of Civil Engineering and Technology (IJCIET), 8 (9), 82-90.

Nwachukwu, C., Chladkova, H., Zufan, P. (2017). The relationship between entrepreneurial orientation, Entrepreneurial competences, entrepreneurial Leadership, and firm performance: a proposed model. Business Trends, 7 (1), 3-16.

Oni, O., Agbobli, E.K., Iwu, C.G. (2019). Entrepreneurial orientation and performance of small business in Vryburg Region North West Province South Africa. Journal of Reviews on Global Economics, 8, 63-71. https://doi.org/10.6000/1929-7092.2019.08.07

Perera, T.R. (2018). Sri Lanka must develop an entrepreneurial culture to achieve suitable development. Retrieved from: https://www.ft.lk/Columnists/Sri-Lanka-mustdevelop-an-entrepreneurial-culture-to-achieve-suitabledevelopment/4-662277 (12.06.2020).

Peric, I., Grladinovic, T., Kropivsek, J., Greger, K. (2017). Relationship between entrepreneurial competencies and firm performance: A study on manufacturing SMEs in Croatia. $28^{\text {th }}$ International Conference on Wood Science and Technology: Implementation of Wood Science in Woodworking Sector.

Pulka, B.M., Ramli, A., Mohamad, A. (2018). Examining the moderating role of external environment on the firms' resources and performance of SMEs in Nigeria: A pilot study. IOSR Journal of Business and Management (IOSR-JBM), 20 (11), 20-26.

Putniņš, T.J., Sauka, A. (2019). Why does entrepreneurial orientation affect company performance? Strategic Entrepreneurship Journal, 14 (4), 1-47. https://doi.org/10.1002/sej.1325

Radulovich, L., Javalgi, R., Scherer, R.F. (2018). Intangible resources influencing the international performance of professional service SMEs in an emerging market: Evidence from India. International Marketing Review, 35 (1), 113-135. https:// doi.org/10.1108/IMR-06-2016-0130

Ranasinghe, D.M., Damunupola, A.K.A., Kumara, P.H.T., Sammani, U.G.O. (2020). Challenges and opportunities for community based tourism development in Kithulgala. Proceedings of the International Research Conference, Uva Wellassa University, Sri Lanka. Retrieved from: http://www.uwu.ac.lk/wp-content/ uploads/2020/proceeding_of_ircuwu2020.pdf (30.07.2020).

Ranasinghe, R. (2015). Evaluation of homestay accommodation supply in Sri Lanka. International Journal of Multidisciplinary Research and Development, 2 (2), 442-447.

Rauch, J. (2015). Disruptive entrepreneurship is transforming U.S. health care. Center of Effective Public Management. Retrieved from: https://www.brookings.edu/wp-content/uploads/2016/06/rauch.pdf (30.03.2020).

Reijonen, H., Tammi, T., Saastamoinen, J. (2015). SMEs and public sector procurement: Does entrepreneurial orientation make a difference? International Small Business Journal, 34 (4), 468486. https://doi.org/10.1177/0266242614556661

Sajeena, H. (2020). An overview of entrepreneurial competences. Our Heritage (UGC Care Journal), 6 (8), 55-61. 
Sarwoko, E., Nurfarida, I.N. (2018). Entrepreneurial orientation and entrepreneurial competence of small and medium enterprises. Annual Conference on Social Sciences and Humanities (ANCOSH 2018) - Revitalization of Local Wisdom in Global and Competitive Era. Retrieved from: https://www. researchgate.net/publication/329496944_Entrepreneurial_ Orientation_and_Entrepreneurial_Competency_of_ Small_and_Medium_Enterprises (20.03.2021). https://doi. org/10.5220/0007424005270530

Sarwoko, E., Surachman, A., Hadiwidjojo, D. (2013). Entrepreneurial characteristics and competence as determinants of business performance in SMEs. International Organization of Scientific Research Journal of Business and Management, 7 (3), 31-38. https://doi.org/10.9790/487X-0733138

Sikari, S. (2018). Women entrepreneurship in tourism industry: A study on women entrepreneurial opportunities in tourism industry of West Bengal. IOSR Journal of Business and Management, special issue, 60-67.

Sok, P., Snell, L., Lee, W.J., Sok, K.M. (2017). Linking entrepreneurial orientation and small service firm performance through marketing resources and marketing capability: A moderated mediation model. Journal of Service Theory and Practice, 27 (1), 231-249. https://doi.org/10.1108/JSTP-01-2016-0001

Solikahan, E.Z., Mohammad, A. (2019). Development of entrepreneurial orientation. International Journal of Applied Business and International Management, 4 (1), 31-37. https://doi.org/10.32535/ ijabim.v4i1.380

Sozuer, A., Altuntas, G., Semercioz, F. (2017). International entrepreneurship of small firms and their export market performance. European Journal of International Management, 11 (3), 365-382. https://doi.org/10.1504/EJIM.2017.083874

Sriyani, G.T.W. (2018). Problems and challenges of homestay tourism in Sri Lanka. Paper presented at the International Conference on Management and Economics (ICME) - 2018, University of Ruhuna, Sri Lanka.

Sulistyo, H., Ayuni, S. (2020). Competitive advantages of SMEs: The roles of innovation capability, entrepreneurial orientation, and social capital. Contaduría y Administración, 65 (1), 1-18. https://doi.org/10.22201/fca.24488410e.2020.1983

Sumithra, N.K. (2020). The relationship between motivation and retention in the homestay business in Ella. $3^{\text {rd }}$ Research Conference on Business Studies (RCBS), Vavuniya Campus of the University of
Jaffna, Sri Lanka. Retrieved from: http://repo.lib.jfn.ac.lk/ujrr/bitstream/123456789/2621/1/The\%20relationship $\% 20$ between $\% 20$ motivation\%20and \%20retention\%20in\%20the \%20homestay $\% 20$ business\%20in\%20Ella.\%20\%5BPDF\%5D.pdf (30.03.2020).

Tehseen, S., Ramayah, T. (2015). Entrepreneurial competences and SMEs business success: The contingent role of external integration. Mediterranean Journal of Social Sciences, 6 (1), 50-61. https://doi.org/10.5901/mjss.2015.v6n1p50

Tehseen, S. (2017). Cultural orientations, entrepreneurial competences, Entrepreneurial innovativeness and business success: A comparative study among Malaysian ethnic entrepreneurs in wholesale and retail SMEs. Doctoral dissertation. Universiti Kuala Lumpur.

Vashishtha, S. (2021). Assessing the entrepreneurial orientation: A study of Kurukshetra University. International Journal of Business Marketing and Management (IJBMM), 6 (1), 1-5.

Wales, W.J. (2015). Entrepreneurial orientation: A review and synthesis of promising research direction. International Small Business Journal, 34 (1), 3-15. https://doi.org/10.1177/0266242615613840

Wernerfelt, B. (1984). A resource-based view of the firm. Strategic Management Journal, 5 (2), 171-180. https://doi.org/10.1002/ smj.4250050207

Wijesundara, N. Gnanapala, A.C. (2015). Difficulties and challenges related to the development of homestay tourism in Sri Lanka. Tourism, Leisure and Global Change, Lombok, Indonesia. Retrieved from: https://www.researchgate.net/publication/308266081_ DIFFICULTIES_AND_CHALLENGES_RELATED_TO_ THE_DEVELOPMENT_OF_HOMESTAY_TOURISM_IN_ SRI_LANKA_Creative_Commons_Copyright_NC-BY-ND (30.03.2020).

Witchayakawin, P., Aziz, Y.A., Mahomed, A.S.B.B., Abdullah, N.H.B. (2020). Factors on development of communitybased tourism (CBT) in Phitsanulok Province of Thailand. Journal of Critical Reviews, 7 (12), 75-85. https://doi.org/10.31838/ jcr.07.12.12

Yong, K., Hassan, R.A. (2017). A conceptual framework of community participation and entrepreneurial success towards the homestay business in Sabah, Malaysia. Academy of Entrepreneurship Journal, 25 (1).

Yusuff, Y.Z.M., Bakar, A.A., Ahmad, S. (2016). Determinant factors of women entrepreneurs' business performance: A conceptual Framework. Journal of Global Business and Social Entrepreneurship (GBSE), 1 (1), 55-67. 